\title{
Psychiatric and socioeconomic aspects as possible predictors of compulsive buying behavior
}

\author{
Aspectos psiquiátricos e socioeconômicos como possíveis preditores de \\ comportamento de compras compulsivas
}

\author{
Priscilla Lourenço Leite, Adriana Cardoso Silva*
}

\begin{abstract}
Introduction: Compulsive buying can be characterized as an almost irresistible urge to buy various items. Compulsive buying disorder is a subject of growing interest to health professionals. It is a current issue and the prevalence rate in the global population is around 5 to $8 \%$.

Objectives: The main objective of this study was to identify predictors of compulsive buying in the Brazilian population, assessing possible relationships between compulsive buying, depression and anxiety.

Methods: The Richmond Compulsive Buying Scale was administered to screen for compulsive buying and the Hospital Anxiety and Depression Scale was used to assess anxiety and depression in a sample of 359 participants. Pearson coefficients were used to test for correlations.

Results: Our study identified an interaction between female gender and compulsion to purchase. Furthermore, people's occupations also appear to have an influence on the problem. We found a correlation between depressive symptoms and oniomania.

Conclusion: Our study has certain limitations, such as the difficulty in recruiting individuals with compulsive buying disorder. Since compulsive buying is a phenomenon that is seldom investigated, it therefore remains unidentified. However, this is nevertheless a pioneering paper on the Brazilian population.
\end{abstract}

Keywords: Regression, epidemiology, depression, anxiety, compulsive behavior.

\section{Introduction}

Compulsive buying disorder is a subject that has been attracting growing interest among health professionals, ${ }^{1}$ largely because of the increase in studies and publications about compulsive behaviors. ${ }^{2}$

\section{Resumo}

Introdução: A compra compulsiva pode ser caracterizada como um desejo quase irresistível de obter vários itens. O transtorno do comprar compulsivo tem sido objeto de interesse crescente para os profissionais de saúde. Considerado um problema atual, sua taxa de prevalência é de cerca de 5 a $8 \%$ na população mundial.

Objetivos: $O$ principal objetivo desta pesquisa foi identificar os preditores da compulsão por comprar na população brasileira, avaliando possíveis relações entre compra compulsiva, depressão e ansiedade.

Métodos: A Escala de Compras Compulsivas Richmond Adaptada foi utilizada para rastreio do comprar compulsivo, e a Escala Hospitalar de Ansiedade e Depressão, para avaliar ansiedade e depressão, em uma amostra de 359 participantes. As correlações foram determinadas usando o teste de Pearson.

Resultados: Foi identificada em nosso estudo uma interação entre sexo feminino e compulsão por compras. Além disso, a ocupação parece interferir no problema. Encontramos uma correlação entre sintomas depressivos e oniomania.

Conclusão: Nosso estudo apresenta algumas limitações, tais como a dificuldade em recrutar indivíduos com transtorno do comprar compulsivo. Por ser um tema pouco explorado, há uma dificuldade em identificar indivíduos acometidos. No entanto, este é um ensaio pioneiro na população brasileira.

Descritores: Regressão, epidemiologia, depressão, ansiedade, comportamento compulsivo.

Originally referred to as oniomania by Kraepelin, who described it in 1990, compulsive buying can be characterized as an irresistible, recurrent and dominating desire to purchase a variety of items. ${ }^{3,4}$ This impulse is uncontrollable and patients can only find relief from the tension invoked by indulging in excessive

\footnotetext{
* Laboratório do Pânico e Respiração, Instituto de Psiquiatria, Universidade Federal do Rio de Janeiro (UFRJ), Instituto Nacional de Ciência e Tecnologia Medicina Translacional (INCT-TM), Conselho Nacional de Desenvolvimento Científico e Tecnológico (CNPq), Rio de Janeiro, RJ, Brazil.

Financial support: Coordenação de Aperfeiçoamento de Pessoal de Nível Superior (CAPES).

Submitted Sep 16 2015, accepted for publication Oct 26 2015. No conflicts of interest declared concerning the publication of this article.

Suggested citation: Leite PL, Silva AC. Psychiatric and socioeconomic aspects as possible predictors of compulsive buying behavior. Trends Psychiatry Psychother. 2016;38(3):141-146. http://dx.doi.org/10.1590/2237-6089-2015-0057
} 
buying. However, the feeling of wellbeing produced by the reduction in stress is quickly replaced by feelings of guilt. ${ }^{5}$ This behavior is considered an addiction, a social phenomenon, to which many North-Americans succumb in attempts to fill feelings of emptiness. ${ }^{6}$

O'Guinn \& Faber ${ }^{7}$ have defined compulsive buying as "chronic, repetitive purchasing that becomes a primary response to negative events or feelings, [is] very difficult to stop, and ultimately results in harmful consequences" (p. 155).

Compulsive buying behavior interferes with the individual's social, professional and occupational performance, may create financial problems and, over the long-term, can lead to debt. 8 In addition to guilty feelings resulting from purchasing items, patients may also feel regret, family and legal problems can be caused by their inability to manage money and they may accumulate debts to enable them to continue buying. ${ }^{7,9,10}$

Since the problem does not have uniform characteristics, there is no definitive classification. Some researches define compulsive buying as a disorder related to addiction, classifying it with addictions such as alcoholism and abuse of other drugs. ${ }^{10,11}$ However, the problem can also be defined as a compulsion, which would mean it is related to obsessive-compulsive disorder (OCD). ${ }^{12}$ As such, there is not yet a consensus definition of compulsive buying. Although there is no definition in the latest edition of the Diagnostic and Statistical Manual of Mental Disorders (DSM-V) ${ }^{13}$ which does not classify compulsive buying as a disorder, McElroy's classification ${ }^{8}$ has been widely accepted and is commonly used in scientific literature on compulsive buying.

It has been estimated that from 6 to $8 \%$ of the population may suffer from compulsive buying. ${ }^{14}$ Some surveys describe high prevalence rates among women, ranging from 80 to $95 \% .1$ In contrast, a German study has suggested that there is no difference between the prevalence of compulsive buying among women and men. ${ }^{15}$

For several reasons, age at onset tends to be from 18 to 30 years old, ${ }^{8,16,17}$ the disorder appears to be influenced by countries' levels of development and its cause may be related to higher degrees of industrialization, with the exception of the higher social classes in underdeveloped countries. ${ }^{3,18}$

The main psychiatric comorbidities associated with compulsive buying include anxiety and mood disorders, eating disorders and disorders resulting from ingestion of chemicals, in addition to OCD and the compulsive hoarding syndrome. ${ }^{19}$

This study aims to evaluate the main characteristics of compulsive buying among Brazilians together with the factors that predispose towards it and to reflect on the relationships between buying compulsion, depression and anxiety.

\section{Methods}

\section{Participants}

This study recruited 359 participants aged 19 to 66 years old. The sample was convened through online calls that were conducted from September 2012 to June 2013 and sampling attempted to cover different social strata in order to represent the general population.

\section{Instruments}

A semi-structured questionnaire was prepared to collect sociodemographic data and the commitment level associated with compulsive buying was investigated using an adapted version of the Richmond Compulsive Buying Scale (RCBSA). ${ }^{20}$ The RCBSA is a scale for assessment of the symptoms of compulsive buying in two domains. It measures both compulsive buying symptoms and impulse control disorder symptoms using 6 items. Signs and symptoms of anxiety and depression were assessed using the Hospital Anxiety and Depression Scale (HADS). The HADS comprises 14 items, 7 of which assess anxiety and 7 of which evaluate depression rates. Ratings vary from 0 to 3 and the maximum score for each sub-scale is 21 points.

\section{Procedures}

Since the instruments were administered online via a website, the procedures adopted had to follow specific rules for web-based administration. As such, candidate participants who were called were able to accept or refuse to take part in the survey when they accessed the website. If a participant was interested in taking part in the survey, he/she was required to complete a Free and Informed Consent Form, as well as a protocol containing the three survey instruments and summarized instructions for completing each instrument. This study was approved by an ethics committee.

The chi-square test was used to analyze demographic variables. Pearson and Spearman coefficients were used to demonstrate clinical correlations, using the Statistical Package for the Social Sciences (SPSS), version 18.0. Linear regression analysis was used to verify the effects of compulsive buying on the explanatory variables. Semi-literate people and those less than 18 years old were excluded. 


\section{Results}

A total of 359 participants were evaluated, of whom 298 (83\%) were female, 209 (58.2\%) were single, 163 (45.4\%) had finished college, $102(28.4 \%)$ were not working or were students at the time they were assessed, 145 (40.4\%) had median individual wages greater than or equal to US\$ 896.00 , and 265 (73.8\%) declared that they did not have children. The greater part of the population interviewed were from the Southeast of Brazil (69.4\%) (Table 1).

Table 1 - Characteristics of the study sample

\begin{tabular}{|c|c|c|c|c|}
\hline & $\begin{array}{l}\text { Total sample } \\
(n=359)\end{array}$ & $\begin{array}{l}\text { Non-CB } \\
(n=322)\end{array}$ & $\begin{array}{c}\text { CB } \\
(n=37)\end{array}$ & $\begin{array}{c}\text { Comparison non CB } \\
\text { vs. CB }\end{array}$ \\
\hline $\begin{array}{l}\text { Age, mean } \pm \text { standard deviation } \\
\text { (minimum-maximum) }\end{array}$ & $\begin{array}{l}31.87 \pm 10.95 \\
(19-66)\end{array}$ & $\begin{array}{c}31.79 \pm 11.09 \\
(19-66)\end{array}$ & $\begin{array}{l}32.62 \pm 9.70 \\
(21-61)\end{array}$ & \\
\hline \multicolumn{5}{|l|}{ Gender } \\
\hline Male & $61(17)$ & $61(18.9)$ & - & $x^{2}=8.44, p=0.004$ \\
\hline Female & $298(83)$ & $261(81.1)$ & $37(100)$ & \\
\hline \multicolumn{5}{|l|}{ Marital status } \\
\hline Single & $209(58.2)$ & $189(58.7)$ & $20(54.1)$ & \\
\hline Married/stable relationship & $122(34)$ & 109 (33.9) & $13(35.1)$ & $x^{2}=0.84, p=0.83$ \\
\hline Separated/divorced & $27(7.5)$ & $23(7.1)$ & $4(10.8)$ & \\
\hline Widowed & $1(0.3)$ & $1(0.3)$ & - & $X^{2}=1.71, p=0.191$ \\
\hline Children & $94(26.2)$ & $81(25.2)$ & $13(35.1)$ & $x^{2}=2.47, p=0.65$ \\
\hline \multicolumn{5}{|l|}{ Education } \\
\hline High school complete & $8(2.2)$ & $8(2.5)$ & - & \\
\hline College level incomplete & $108(30.1)$ & $96(29.8)$ & $12(32.4)$ & \\
\hline College level complete & $163(45.4)$ & $145(45)$ & $18(48.6)$ & \\
\hline Full master & $68(18.9)$ & $61(18.9)$ & $7(18.9)$ & \\
\hline PhD degree & $12(3.3)$ & $12(3.7)$ & - & \\
\hline Occupation & & & & $x^{2}=12.46, p=0.02$ \\
\hline Student - no job & $102(28.4)$ & $94(29.2)$ & $8(21.6)$ & \\
\hline Stay-at-home & $4(1.1)$ & $2(0.6)$ & $2(5.4)$ & \\
\hline Unemployed & $12(3.3)$ & $10(3.1)$ & $2(5.4)$ & \\
\hline Formal employment/public official & $148(41.3)$ & $128(39.8)$ & $20(54.1)$ & \\
\hline $\begin{array}{l}\text { Unregistered or informal } \\
\text { employment/self-employed }\end{array}$ & $84(23.4)$ & $80(24.8)$ & $4(10.8)$ & \\
\hline Retired & $9(2.5)$ & $8(2.5)$ & $1(2.7)$ & \\
\hline Median individual income & & & & $x^{2}=6.74, p=0.24$ \\
\hline$\geq \operatorname{US} \$ 2,914.00$ & $58(16.1)$ & $55(17.1)$ & $3(8.1)$ & \\
\hline$\geq$ US\$ 896.00 & $163(45.4)$ & $139(43.1)$ & $22(59.4)$ & \\
\hline$\geq$ US\$ 325.00 & $72(20.1)$ & $66(20.5)$ & $6(19.0)$ & \\
\hline$\geq$ US\$ 217.00 & $15(4.2)$ & $16(4.9)$ & - & \\
\hline$\leq$ US $\$ 217.00$ & $51(14.2)$ & $46(14.3)$ & $5(13.5)$ & \\
\hline Region & & & & $x^{2}=1.93, p=0.85$ \\
\hline Mid West & $2(0.6)$ & $2(0.6)$ & - & \\
\hline Northeast & $98(27.3)$ & $87(27)$ & $9(24.3)$ & \\
\hline Southeast & $249(69.4)$ & $223(69.2)$ & $28(75.7)$ & \\
\hline South & $6(1.7)$ & $6(1.9)$ & - & \\
\hline Another country & $4(1.1)$ & $4(1.2)$ & - & \\
\hline
\end{tabular}

$\mathrm{CB}=$ compulsive buying.

Data presented as n (\%), unless otherwise specified.

It was found that there were no statistically significant associations between compulsive buying and the categorical variables region, having children or marital status. In contrast, the variable gender did exhibit statistical significance: $x^{2}(2)=8.44 ; p=0.004$ and the variable occupation also exhibited significance: $\mathrm{X}^{2}(2)=12.45 ; \mathrm{p}=0.029$.

Presence of signs and symptoms of anxiety had a weak and inversely proportional correlation with compulsive buying $(r=-0.12 ; p<0.02)$. Depressive symptoms had a weak proportional correlation with oniomania. ( $r=0.11 ; p<0.04)$.

There were no statistically significant relationships between RCBSA scale scores and average wage or age. In view of these results, occupation, gender and depression were considered possible predictors of compulsive buying in the logistic regression analysis (Table 2). 


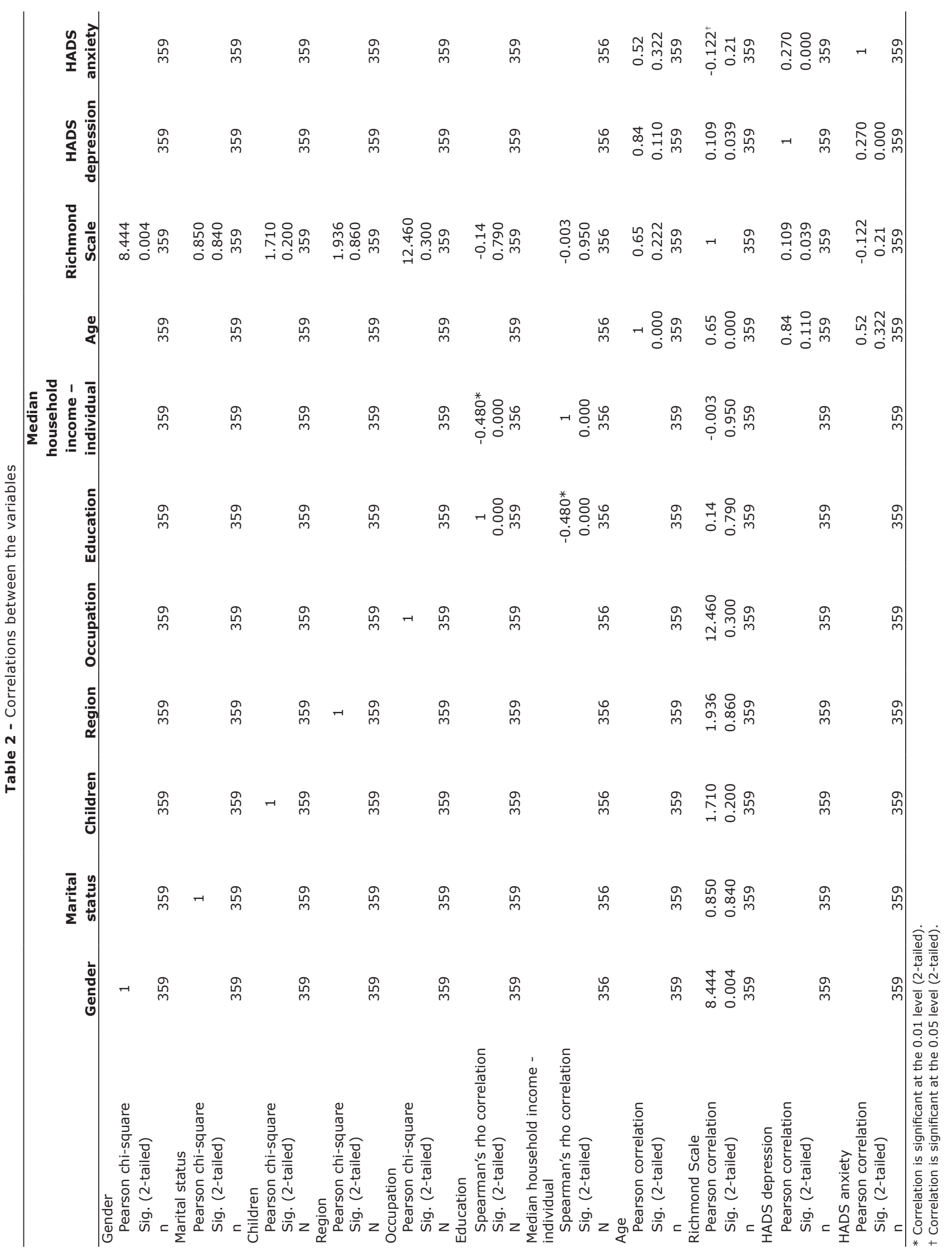


The linear regression analysis suggested a possible influence of the following variables as predictors of compulsive buying: depression, monthly per capita income, occupation, and sex. Results indicated positive associations with compulsive buying for female sex ( $p$ $<0.001$ ), homemakers and people who do not have an employees' identification card (which indicates a formal employment contract) $(p=0.05)$. However, there was no significant association between depression and compulsive buying. This model has a correlation coefficient of $R=$ $0.246\left(R^{2}\right.$ adjusted $\left.=0.42\right)$, which means that the model was capable of predicting $42 \%$ of variation in compulsive buying (Tables 3 and 4).

Table 3 - Regression analysis

\begin{tabular}{lcccc}
\hline Model & R & R square & $\begin{array}{c}\text { Adjusted R } \\
\text { square }\end{array}$ & $\begin{array}{c}\text { Standard } \\
\text { error } \\
\text { of the } \\
\text { estimate }\end{array}$ \\
\hline 1 & 0.153 & 0.024 & 0.021 & 0.30129 \\
2 & 0.246 & 0.060 & 0.044 & 0.29763 \\
3 & $0.246 *$ & 0.061 & 0.042 & 0.29803 \\
\hline
\end{tabular}

* Predictors: (constant), female, unregistered employment, stay-athome, retired, unemployed, student, probable depression.

Table 4 - Regression analysis - coefficients

\begin{tabular}{|c|c|c|c|c|c|c|}
\hline \multirow{2}{*}{\multicolumn{2}{|c|}{ Model }} & \multicolumn{2}{|c|}{$\begin{array}{c}\text { Non- } \\
\text { standardized } \\
\text { coefficients }\end{array}$} & \multicolumn{3}{|c|}{$\begin{array}{l}\text { Standardized } \\
\text { coefficients }\end{array}$} \\
\hline & & B & $\begin{array}{c}\text { Standard } \\
\text { error }\end{array}$ & Beta & $t$ & Sig. \\
\hline \multirow[t]{2}{*}{1} & (Constant) & -1.067 & 0.039 & & 0.000 & 1.000 \\
\hline & Female & 0.124 & 0.042 & 0.153 & 2.932 & 0.004 \\
\hline \multirow[t]{7}{*}{2} & (Constant) & 0.030 & 0.042 & & 0.708 & 0.480 \\
\hline & Female & 0.131 & 0.042 & 0.162 & 3.105 & 0.002 \\
\hline & $\begin{array}{l}\text { Stay-at- } \\
\text { home }\end{array}$ & 0.339 & 0.151 & 0.117 & 2.245 & 0.025 \\
\hline & Student & -0.066 & 0.038 & -0.097 & -1.710 & 0.088 \\
\hline & Unemployed & 0.050 & 0.090 & 0.029 & 0.554 & 0.580 \\
\hline & $\begin{array}{l}\text { Unregistered } \\
\text { employment }\end{array}$ & -0.094 & 0.041 & -0.132 & -2.320 & 0.021 \\
\hline & Retired & -0.006 & 0.102 & -0.003 & -0.059 & 0.953 \\
\hline \multirow[t]{8}{*}{3} & (Constant) & 0.029 & 0.042 & & 0.703 & 0.483 \\
\hline & Female & 0.131 & 0.042 & 0.162 & 3.105 & 0.002 \\
\hline & $\begin{array}{l}\text { Stay-at- } \\
\text { home }\end{array}$ & 0.339 & 0.151 & 0.117 & 2.242 & 0.026 \\
\hline & Student & -0.066 & 0.038 & -0.097 & -1.708 & 0.088 \\
\hline & Unemployed & 0.050 & 0.090 & 0.029 & 0.553 & 0.581 \\
\hline & $\begin{array}{l}\text { Unregistered } \\
\text { employment }\end{array}$ & -0.094 & 0.041 & -0.130 & -2.289 & 0.023 \\
\hline & Retired & -0.006 & 0.102 & -0.003 & -0.058 & 0.954 \\
\hline & $\begin{array}{l}\text { Probable } \\
\text { depression }\end{array}$ & -0.067 & 0.300 & -0.012 & -0.224 & 0.823 \\
\hline
\end{tabular}

\section{Discussion}

The main objective of this study was to identify factors predictive of compulsive buying. Female gender and the occupational variables working without a contract in an informal job or working as a homemaker were found to be predictors. According to the Brazilian Institute for Geography and Statistics (IBGE), $56.1 \%$ of women did not hold formal employment positions in 2010. Among the interviewees identified as compulsive buyers, $100 \%$ were female. These results are consistent with the results of other studies. It is possible to find reports of compulsive buying prevalence rates among women as high as $92 \% .{ }^{21}$ An American survey has suggested that from 80 to $94 \%$ of compulsive buyer are women. These discoveries help to trace the profile of people with compulsive buying disorder.

Other relevant findings relate to socioeconomic factors. With regard to occupation, $64.9 \%$ of the compulsive buyers interviewed were in work at the time of the survey. According to a Spanish survey, 38.6.7\% of the buyers sampled were working. ${ }^{22}$ In our sample, $59.5 \%$ were earning up to US $\$ 896.00$, which was the individual monthly average income and is equivalent to socioeconomic class $D$ (or the lower middle class) in Brazil. According to a German study, ${ }^{15} 31.1 \%$ informed an individual average income of around US\$1261.67, which indicates lower class. That result is similar to what has been observed in this study.

It therefore follows that buying problems are not related to socioeconomic indicators, since it is possible to show that people from lower classes are affected. Of the respondents, $75 \%$ of the compulsive buyers lived in the Southeast of the country, which is the richest region and has the most diversified economy, accounting for around $56.2 \%$ of Brazil's gross domestic product. ${ }^{23}$

Associations were detected between compulsive buying and sociodemographic variables, such as marital status, level of education, age, having children and monthly average income. Although the results indicate that average income does not have a significant association with compulsive buying, it is still possible to discern certain elements of this population's socioeconomic profile: participants with an age of 32.62 years (average age) are most likely to be compulsive buyers.

With regard to the clinical features of the sample studied, although depression was not defined as a predictor factor, it was possible to associate it with compulsive buying. These findings corroborate other studies that have associated these two phenomena. One study identified an association between depressive symptoms and compulsive buying in a German 
population. ${ }^{24}$ Some researches indicate that 21 to $90 \%$ of buyers exhibit the diagnostic criteria for depression. ${ }^{25}$

In our study, $89.2 \%$ of buyers had HADS profiles compatible with depression. The results relating compulsive buying and anxiety are non-significant and do not provide a basis for assessing the association between these variables in the population studied.

The results of this study provide a basis for increasing understanding of the variables that make compulsive buying more likely in the Brazilian population. Since this is a pioneering study, it highlights common characteristics of compulsive buyers. The relationship between female gender and this disorder can be detected in the Brazilian population and the same is true of occupational factors. Furthermore, we also detected a correlation between depressive symptoms and buying compulsion.

Notwithstanding, there are limitations that should be taken into consideration when evaluating the results. Sample size and diversity of the population studied should be better explored in future studies. Another aspect is related to the difficulties in detecting people who exhibit compulsive buying behaviors. This is a problem that is still in the exploratory phase of study and, as a consequence, it is hard to identify. New recognition strategies could enable a wider-ranging study of the predisposing factors and of those who have this compulsion. It would be a good idea to evaluate the impacts of compulsive buying on women and young adults in future studies and also to identify the factors that disseminate and accentuate the problem, in order to try to understand the relationship between compulsive buying and other disorders.

\section{Acknowledgements}

This study was supported by the Coordenação de Aperfeiçoamento de Pessoal de Nível Superior (CAPES).

\section{References}

1. Black DW. Compulsive buying disorder: definition, assessment, epidemiology and clinical management. CNS Drugs. 2001;15:1727.

2. Hollander E, Stein D, Decaria CM, Frenkel M, Trungold S, Liebowitz MR. Obsessive-compulsive related disorders. Washington: American Psychiatric Press; 1993.

3. Koran LM, Faber RJ, Aboujaoude E, Large MD, Serpe RT. Estimated prevalence of compulsive buying behavior in the United States. Am J Psychiatry. 2006;163:1806-12.

4. Lejoyeux M, Haberman N, Solomon J, Adés J. Comparison of buying behavior in depressed patients presenting with or without compulsive buying. Compr Psychiatry. 1999;40:51-6.
5. Kraepelin E. Psychiatrie. 8th ed. Leipzig: Verlag Von Johann Ambrosius Barth; 1915. p. 408-9.

6. Lee S, Mysyk A. The medicalization of compulsive buying. Soc Sci Med. 2004;58:1709-18.

7. O'Guinn TC, Faber RJ. Compulsive buying: a phenomenological exploration. J Consum Res. 1989;16:147-57.

8. McElroy SL, Keck P Jr, Pope HG Jr, Smith JM, Strakowski SM. Compulsive buying: a report of 20 cases. J Clin Psychiatry. $1994 ; 55: 242-8$

9. Christenson GA, Faber JR, de Zwann M, Raymond NC, Specker SM, Ekern MD, et al. Compulsive buying: descriptive characteristics and psychiatric comorbidity. J Clin Psychiatry. 1994; 5:5-11.

10. Black DW. Compulsive buying disorder: a review of the evidence. CNS Spectr. 2007;12:124-32.

11. Krych R. Abnormal consumer behavior: a model of addictive behaviors. Adv Consum Res. 1989;16:745-8.

12. Hollander E. Obsessive-compulsive related disorders. Washington: American Psychiatric Press; 1993.

13. American Psychiatric Association. Diagnostic and Statistical Manual of Mental Disorders, Fifth Edition (DSM-5). Arlington: American Psychiatric Publishing; 2013.

14. Raab G, Elger CE, Neuner M, Weber B. A neurological study of compulsive buying behaviour. J Consum Policy. 2011;34:40113.

15. Mueller A, Mitchell JE, Crosby RD, Gefeller O, Faber RJ, Martin A, et al. Estimated prevalence of compulsive buying in Germany and its association with sociodemographic characteristics and depressive symptoms. Psychiatry Res. 2010;180:137-42.

16. Schlosser S, Black DW, Repertinger S, Freet D. Compulsive buying. Demography, phenomenology, and comorbidity in 46 subjects. Gen Hosp Psychiatry. 1994;16:205-12.

17. Mitchell JE, Burgard $M$, Faber R, Crosby RD, deZwaan $M$ Cognitive behavioral therapy for compulsive buying disorder. Behav Res Ther. 2006;44:1859-65.

18. Faber RJ, O'Guinn TC. A clinical screener for compulsive buying. J Consum Res. 1992;19:459-69.

19. Müller A, Claes L, Georgiadou E, Möllenkamp M, Voth EM, Faber $\mathrm{RJ}$, et al. Is compulsive buying related to materialism, depression or temperament? Findings from a sample of treatment-seeking patients with CB. Psychiatry Res. 2014;216:103-7.

20. Leite $P$, Rangé $B$, Kukar-Kiney $M$, Ridgway $N$, Monroe K, Ribas Junior $R$, et al. Cross-cultural adaptation, validation and reliability of the Brazilian version of the Richmond Compulsive Buying Scale. Rev Bras Psiquiatr. 2013;35:38-043.

21. Dittmar H. Understanding and diagnosing compulsive buying. In: Coombs $\mathrm{RH}$, editors Addictive disorders: a practical handbook. New York: Wiley; 2004. p. 411-50.

22. Otero-López JM, Villardefrancos E. Prevalence, sociodemographic factors, psychological distress and coping strategies related to compulsive buying: a cross sectional study in Galicia, Spain. BMC Psychiatry. 2014;14:101.

23. Lampreia LF. Relatório brasileiro sobre desenvolvimento social. Estud Av. 1995;9:9-74.

24. Mueller A, Mitchell JE, Crosby RD, Gefeller O, Faber RJ, Martin $A$, et al. Estimated prevalence of compulsive buying in Germany and its association with sociodemographic characteristics and depressive symptoms. Psychiatry Res. 2010;180:137-42.

25. Lejoyeux M, Tassian V, Solomon J, Adès J. Study of compulsive buying in depressed persons. J Clin Psychiatry. 1997;58:169-73.

\section{Correspondence:}

Priscilla Lourenço Leite

Laboratory of Panic and Respiration, Institute of Psychiatry

Universidade Federal do Rio de Janeiro - INCT - Translational Medicine

Av. Venceslau Brás, 71, Botafogo

22290-140 - Rio de Janeiro, RJ - Brazil

Tel./Fax: +55 (21) 22952549

E-mail: priscilla.ufrj@gmail.com 